CSDM Views 29

\title{
Key Prerequisites for Integrity in Defence: Role of Parliament
}

Todor Tagarev 


\section{Todor Tagarev, Key Prerequisites for Integrity in Defence: Role of Parliament}

Abstract: In a report to the session "Defence Management Reform and Integrity Building" of the 88th Rose-Roth seminar of the NATO Parliamentary Assembly, Belgrade, 31 March- 2 April 2015, the author outlines three key prerequisites for integrity in defence: having a balanced, adequate, acceptable, and affordable defence policy; assessment of plans, budget proposals, and reports with a view on planned or actual results; and effective cooperation and coordination among key security stakeholders. The report further suggests roles of parliaments and parliamentarian committees on security and defence.

Keywords: integrity, transparency, defence policy, defence budgeting, coordination, parliamentarian oversight, NATO

\section{Тодор Тагарев, Ключови предпоставки за интегритет в отбраната: Роля на парла- мента}

Резюме: В доклада си пред сесията „Рефрорма на отбранителния мениджмънт и утвърждаване на интегритета“" пред 88-я Роуз-Рок семинар на Парламентарната асамблея на НАТО в Белград, 31 март - 2 април 2015 г. авторът очертава три ключови предпоставки за интегритет в отбраната: наличие на балансирана, адекватна, приемлива и реалистична отбранителна политика; оценяване на планове, бюджетни предложения и доклади за изпълнението от гледна точка на планирани и реални резултати; и ефективно сътрудничество и координация между организациите в сектора за сигурност. Докладът предлага още съответни роли на парламента и парламентарни комисии по сигурност и отбрана.

Ключови думи: интегритет, прозрачност, отбранителна политика, бюджет за отбрана, координация, парламентарен контрол, НАТО

This text is licensed under a Creative Commons Attribution-Noncommercial-No Derivative 2.5 Bulgaria License

Editors: Todor Tagarev, Velizar Shalamanov, Venelin Georgiev, Valeri Ratchev 
In this short presentation to the distinguished audience of parliamentarians and representatives of national governments and international organisations I will outline the key prerequisites for integrity in defence and the respective attitude of parliamentarians and parliaments, which may have a positive or a negative impact on defence integrity. For a change, I will not use the word corruption, underlining that integrity means much more than the opposite of "corruption."

In most, if not all countries in the Euroatlantic space, i.e. in NATO member-states and partner countries, there are norms in place for parliamentarian oversight of defence and at least nominal implementation of these norms. That includes for example:

- $\quad$ establishment of a specialised committee in parliament

- appointment of a civilian defence minister

- discussion on the budget for defence and security and its publication.

No doubt, you are familiar with the requirements for transparency, accountability, and integrity to provide for good governance of defence. Therefore, I will not talk today in these terms, that are well known to all of you. Numerous publications of the Geneva Centre for the Democratic Control of Armed Forces (DCAF) address these aspects of governance. They are available in multiple languages, in particular the languages of partner countries, and are freely available to everyone interested. ${ }^{1}$

Today I will suggest somewhat different perspective taking instead a managerial point of view, and will formulate and describe key prerequisites for effective parliamentarian oversight. The top three in my view are:

1. Having a rationalised and internalised defence policy in place;

2. Providing for management for results; and

3. Demanding cooperation and coordination in the provision of security, in particular among security sector organisations.

\section{DEFENCE POLICY}

What does it mean to provide transparency and integrity in defence policy making? Understanding that for some of you this is well known, I will start by offering a definition. ${ }^{2}$

Defence policy is the declaration of the state leadership on the adopted course of action in the area of defence that determines or guides future defence decisions and actions.

1 See in particular Hans Born, Philipp Fluri, and Anders Johnsson, Parliamentary Oversight of the Security Sector (Geneva: DCAF, 2003); Hans Born, Philipp Fluri, Simon Lunn, eds., Oversight and Guidance: The Relevance of Parliamentary Oversight for the Security Sector (Geneva: DCAF, 2010); Todor Tagarev, ed., Building Integrity and Reducing Corruption in Defence: A Compendium of Best Practices (Geneva: DCAF, 2010).

2 For a detailed discussion on defining defence policy see Todor Tagarev, "The Art of Shaping Defense Policy: Scope, Components, Relationships (but no Algorithms)," Connections: The Quarterly Journal 5, no. 1 (Spring-Summer 2006): 15-34, available at http://dx.doi.org/10.11610/Connections.05.1.03. 
This declaration defines:

- Goals, through elaboration of of missions of the armed forces and levels of ambition;

- Ways to achieve these goals, sometimes referred to as "defence strategy"3; and

- Means, i.e. the future armed forces or, more generally, the defence capabilities the country will develop and maintain.

All these need to be balanced, with clear understanding of planning risks ${ }^{4}$ and the required resource allocation. Further, as the late Prof. David Greenwood eloquently put it, ${ }^{5}$ this declaration needs to be:

- $\quad$ Adequate to the current and foreseen security environment;

- Acceptable to the society, ${ }^{6}$ allies, key partners, and in view of international norms;

- Affordable, i.e. the country has at its disposal and is ready to allocate to defence the foreseen human, technological, and financial resources.

Another question is who in the definition above is "the state leadership." Practices in this regard differ. In some countries, this is the senior executive body-a Cabinet or Council of Ministers-which adopts a defence policy document, often called "Defence White Paper," and announces it publically. In other countries this document is discussed and voted by the Parliament.

In any case, transparency and integrity mean not only that the document is public and publically discussed, but also that it presents a balanced, adequate, acceptable, and affordable policy. If this is not the case, it cannot perform its role to determine or guide future decisions and actions in defence, thus increasing significantly the challenges of assigning responsibilities and providing for accountability in the implementation of defence policy.

\section{MANAGEMENT FOR RESULTS}

The parliament plays an important role in providing for results-oriented implementation of defence policy. Even though it is the Executive that manages defence, and the Parliament may not hold a vote on the Defence White Paper (or an equivalent document), it still holds the power of the purse.

Key in this regard, and the second vital prerequisite for integrity in defence is to budget for results. This means that budget proposals, discussions, decisions, reports, and accounts are focused on the planned and actually achieved results (e.g. the levels of defence capabilities vis-a-vis stated goals) and not just on the amount of money allocated to or spent on defence.

3 See, for example, the 2008 National Defense Strategy of the United States at www.defense.gov/news/2008\%20National\%20Defense\%20Strategy.pdf.

$4 \quad$ Called also "future challenges risks" - Ibid., p. 22.

5 David Greenwood, ed., Transparency and Accountability in South-East European Defence (Sofia: DCAF and George C. Marshall Association, 2003).

$6 \quad$ Recently, Lithuania decided to re-introduce conscript service. If we take the example of a 30-year old Lithuanian, medical doctor with a PhD from a Western University, specialising brain surgery, the question is what policy is in the best societal interest and how it is reflected in legal regulations, adopted by Parliament. 
There are well established tools for that purpose, such as the programme-based (or "policies-based") budgeting and the respective Planning, Programming, and Budgeting Systems, or PPBS. ${ }^{7}$ However, there are only few, and then only partial examples of good practice in resultsoriented budgeting from Eastern and South-Eastern Europe.

And if I allow myself to be somewhat blunt, when parliaments and parliamentarian committees discuss and vote on defence budgets only in terms of money allocations overall and in budget categories, they do not actually understand what they vote for.

\section{COOPERATION AND COORDINATION IN THE PROVISION OF SECURITY}

Defence is hardly ever guaranteed by examining the defence establishment alone. And vice versa, armed forces are expected to and do contribute to the response to various incidents and crises. Traditionally, this has been the case in natural disasters and industrial catastrophes. By now, we expect a military element in countering the threat of terrorism at home and in searching for cybersecurity and cyber defence. And hybrid warfare is certainly a phenomenon that cannot be addressed only by or without the military.

The substance of the matter is that new threats and challenges do not fit nicely into the remit of one or another security sector organisation. We need to provide for a smooth cooperation and coordination in the provision of security, as a minimum among the security sector organisations.

In terms of operational coordination, the Parliament needs to make sure that security sector organisations do not react ad hoc, but have in place all necessary norms, arrangements, plans, and training for effective joint and multiagency response to any foreseen kind of crisis.

In addition to that, we need to make sure that organisational and budgeting decisions do not strengthen existing stovepipes, nor do we create a new agency-a new bureaucracy if you wish-when a new problem emerges.

Instead, security and defence committees, and the parliament as a whole, need to make sure that the security and defence capabilities of the nation are developed in the most effective and efficient manner, that there are neither gaps nor duplication. The capabilities of security sector organisations must be complementary and interoperable. Security sector organisations need to pool their resources and have all required plans in place to share them when necessary. ${ }^{8}$

Among the parliamentary tools to achieve this are deliberations on executive policies, budget proposals and implementation reports, along with more focused inquiries on capability development programmes, procurement cases, and efficiency of security expenditures.

See, for example, Hari Bucur-Marcu, Philipp Fluri, Todor Tagarev, eds., Defence Management: An Introduction (Geneva: DCAF, 2009); and Milton L. Tulkoff, C. Vance Gordon, Rachel D. Dubin, and Wade P. Hinkle, Planning, Programming, and Budgeting System (PPBS)/Multi-year Programming Reading Guide, IDA Document D-4057 (Alexandria, VA: Institute for Defense Analysis, September 2010).

$8 \quad$ One possible methodological approach is presented in Todor Tagarev, "Capabilities-based Planning for Security Sector Transformation," Information \& Security: An International Journal 24 (2009): 27-35, available at http://dx.doi.org/10.11610/isii.2404. 


\section{CONCLUSION}

The reference to management may seem mundane or even irrelevant to a parliamentarian or a security and defence committee in Parliament. Nevertheless, the understanding of basic concepts and their incorporation in practice is crucial for provision of integrity in defence.

Otherwise, when the Parliament votes on a defence policy and budgets that lack transparency and integrity, it not only shares responsibility with the cabinet, but actually relieves the Executive from the obligation to formulate an effective defence policy and implement it with a reasonable level of efficiency.

There are good practices that can be utilised to implement the priorities of defence management reform-integrity of defence policy, budgeting for results, and effective cooperation and coordination among key security stakeholders-to the benefit of the society to which a parliamentarian serves.

\section{REFERENCES}

Born, Hans, Philipp Fluri, Anders Johnsson, eds. Parliamentary Oversight of the Security Sector, Geneva: DCAF, 2003.

Born, Hans, Philipp Fluri, Simon Lunn, eds. Oversight and Guidance: The Relevance of Parliamentary Oversight for the Security Sector, Geneva: DCAF, 2010.

Bucur-Marcu, Hari, Philipp Fluri, Todor Tagarev, eds. Defence Management: An Introduction, Geneva: DCAF, 2009.

Tagarev, Todor, ed. Building Integrity and Reducing Corruption in Defence: A Compendium of Best Practices, Geneva: DCAF, 2010.

Tagarev, Todor. "Capabilities-based Planning for Security Sector Transformation," Information \& Security: An International Journal 24 (2009): 27-35, available at http://dx.doi.org/10.11610/isij.2404

Tagarev, Todor. "The Art of Shaping Defense Policy: Scope, Components, Relationships (but no Algorithms)," Connections: The Quarterly Journal 5, no. 1 (Spring-Summer 2006): 15-34, available at http://dx.doi.org/10.11610/Connections.05.1.03.

Tulkoff, Milton L., C. Vance Gordon, Rachel D. Dubin, and Wade P. Hinkle. Planning, Programming, and Budgeting System (PPBS)/Multi-year Programming Reading Guide, IDA Document D-4057. Alexandria, VA: Institute for Defense Analysis, 2010. 